\title{
Factors associated with nursing workload in three intensive care units
}

\author{
Factores asociados a la carga de trabajo de enfermería en tres Unidades de Cuidado Intensivo \\ Fatores associados à carga de trabalho de enfermagem em três Unidades de Terapia Intensiva
}

How to cite this article:

Cárceres Rivera DI, Torres CC, López Romero LA. Factors associated with nursing workload in three intensive care units. Rev Esc Enferm USP. 2021;55:e20200272. doi: http://dx.doi.org/10.1590/1980-220X-REEUSP-2020-0272.

\section{Diana Isabel Cáceres Rivera ${ }^{1}$ \\ Claudia Consuelo Torres ${ }^{2}$ \\ D Luis Alberto López Romero ${ }^{3}$}

${ }^{1}$ Universidad Cooperativa de Colombia, Facultad de Enfermería, Grupo de Investigación GIFOSABI, Bucaramanga, Santander, Colombia.

${ }^{2}$ Universidad de Santander, Facultad Ciencias de la Salud, Programa de Enfermeria, Grupo de Investigación Everest, Santander, Colombia.

${ }^{3}$ Fundación Cardiovascular de Colombia, Grupo de Investigación GIDCEN.

Floridablanca, Santander, Colombia.

\begin{abstract}
Objective: To determine the nursing workload in intensive care units (ICUs) and the factors associated with the Nursing Activities Score (NAS). Method: An analytical cross-sectional study was carried out in three ICUs in Bucaramanga, Colombia, between February 2018 and February 2020. The nursing workload was estimated based on the NAS. A descriptive and bivariate analysis stratified by ICU was performed using a robust multiple linear regression model, and the factors associated with the nursing workload ( $p<0.05)$ were estimated. Results: In this study, 362 records were included. The median NAS was 68.1 points (Q1:47.2-Q3:116.7). APACHE II ( $\beta=3.13$, CI: $95 \% 2.28 ; 3.98)$, days of stay in ICU $\geq 3(\beta=16.78$, CI: $95 \% 6.15 ; 27.41)$, surgery provenance service $(\beta=22.31$, CI: $95 \% 9.76 ; 34.86)$, and traumatology and emergencies diagnostic category $(\beta=33.72$, CI 95\%: 9.90; 57.53) were associated with high NAS scores. Conclusion: The nursing staff spend approximately $70 \%$ of their time on a single patient, and administrative work takes up most of their time. Hospital stays of longer than 3 days, high APACHE II score, coming from the surgery department, and having a diagnosis of trauma and emergency were associated with a high workload.
\end{abstract}

DESCRIPTORS

Workload; Critical Care Nursing; Intensive Care Units. 


\section{INTRODUCTION}

The care activities performed by nursing professionals in an intensive care unit (ICU) vary according to the performance site and institutional policies. Furthermore, the length of working hours and the number of patients influence their performance.

There is little evidence of the roles that nursing professionals in Colombia carry out in ICU in daily care practice. Workload-related data are also insufficient. It has been described in a very limited manner in our environment, for example, that the assigned tasks are reduced to activities such as administering and supervising medicines and blood transfusions and other administrative tasks, while technicians or assistants are involved in direct care ${ }^{(1)}$. Moreover, there is no consensus to determine the nurse-patient ratio in such units in our context. It is also known that as the tasks increase, the greater is the risk of failing to comply with them or of their efficiency and quality decreasing. Besides, for each additional patient assigned to a nurse, the mortality rate increases ${ }^{(2)}$. Similarly, the influence of workload on the occurrence of adverse events has been described, making it necessary to constantly assess the nurse-patient ratio to ensure the correct sizing of the workforce and safety in the care provided ${ }^{(3)}$.

In line with the above observations, to calculate the nurse-patient ratio and describe the activities carried out on a working day, several tools have been employed over the years, such as the Nursing Activities Score (NAS). This score has been described among other instruments as the most globally used score to measure the workload ${ }^{(4)}$. This instrument enables the workload to be calculated as well as the direct and indirect care activities that are mostly carried out by ICU nurses through a list of activities grouped according to categories ${ }^{(5)}$.

On the other hand, several studies have researched the factors that are associated with workload. Excessive nursing workload and the severity of the patient's clinical condition have been identified as risk factors. A recent review of literature reiterates factors such as the risk of death calculated by APACHE II (Acute Physiology and Chronic Health Evaluation II) or SAPS (Simplified Acute Physiology Score), the patient's gender, and even the type of ICU, including intermediate units and coronary units ${ }^{(6)}$.

Understanding the activities performed by nursing professionals in the ICU as well as the workload or the time required is essential for countries such as Colombia, where scientific evidence is required to improve the working conditions of these professionals, which has a direct impact on the quality indicators of such units. Hence, the objective of this study was to determine the workload of the nursing staff in the ICU and the factors associated with the NAS score.

\section{METHOD}

\section{Desig of Study}

Analytical cross-sectional study
LOCAL

This study was carried out in three ICUs in Bucaramanga, Colombia, between February 2018 and February 2020. Convenience sampling was used, and a total of 362 patient records in three ICUs were analyzed.

\section{Selection Criteria}

Patients over the age of 18 years who had an intermediate or full ICU stay of $\geq 48$ hours at all three institutions were included in the study. Those with a medical diagnosis and written order in medical history for maintaining or continuing in the ICU, excluding the patients who had a transfer pending to a ward or were in palliative care, were included. Information was obtained from a total of 75 nursing professionals in the three ICUs who voluntarily accepted their participation in the study. Those who did not meet this requirement were excluded by restriction or modification of their employment obligations.

The participating ICUS were all-purpose ICUs, i.e., patients were treated from both medical and surgical pathologies, including cardiovascular surgery. The number of patients who were given the measurements was proportional to the number of monthly discharges for each unit.

\section{Instrument And Measurements}

The variables defined in this study are as follows:

NAS (dependent variable): It is a widely used scale that measures the average time spent by a professional nurse on a 12-hour morning shift across seven categories subdivided into 23 activities. These categories include basic activities such as continuous monitoring, drug administration, education and administration activities, and specific interventions in ventilatory, cardiovascular, renal, neurological, and metabolic support. Additionally, some ICU-specific activities ${ }^{(5)}$ are included.

The NAS was obtained through self-reporting by the participating nursing professionals after the completion of the shift in the ICU, which was recorded in paper format by a duly trained surveyor.

Sociodemographic variables (independent variables): Age, gender, marital status, level of education, socioeconomic stratum, occupation, and social security.

Health status clinical variables (independent variables): Provenance service, patient diagnostic category, mortality, ICU type, days of hospitalization, APACHE II score, and SOFA score.

ICU-related variables (independent variables): Total number of ICU patients, number of nurses per shift, and percentage of unit occupancy.

\section{Data Collection}

Information collection was carried out by three nurses duly trained by the main researcher, who at the end of each shift interviewed the nurses and organized the collected data in a physical format. This format was previously structured by the authors with sociodemographic data, clinical information related to the ICU, and NAS. Data related to 
the patient's clinical condition were reviewed in the electronic medical history. Later, the nurses typed the information obtained from the three centers to the properly coded Excel template, where typing errors were validated and corrected. Finally, one of the researchers wiped the database and imported it into the STATA version 14.0 program to perform the relevant analysis.

\section{Data Analysis and Treatment}

A descriptive analysis was performed using the sociodemographic, clinical, and health status variables that were stratified by the collection center. The continuous variables were described as median accompanied by the first and third quartiles since they did not present a normal distribution according to Shapiro-Wilk and sktest statistical tests, while polytomical nominal variables were described as absolute and relative frequencies.

Subsequently, a bivariate analysis was performed by the collection center comparing nominal variables using the Pearson's square Ji test, such as gender, marital status, educational level, socioeconomic stratum, occupation, social security, provenance service, diagnostic category of the patient, mortality, type of ICU, as well as comparison of medians for continuous age variables, days of hospitalization, APACHE II score, SOFA score, total number of patients in ICU, number of nurses per shift, unit's percentage of occupancy, as well as an analysis of the overall score's trend using Kruskal-Wallis test for each of the NAS activities. In addition, robust simple linear regressions were performed to estimate the effect of each factor on the NAS score, and simple linear regressions were carried out for each of the independent variables of interest defined in the literature by the clinical expertise of the researchers (age, gender, provenance service, diagnostic category, APACHE II, ICU days of stay, and IPS).
Finally, a robust multiple linear regression model was designed using NAS as the outcome and gender and age as well as by varying the health status and ICU as the patient's provenance service, days of stay in the ICU, diagnostic category and Apache II score as the possible major sociodemographic variables. A p-value of $<0.05$ was considered significant. All statistical tests were performed in two queues. The data were analyzed using the STATA statistical program, version $14.0^{(7)}$.

\section{Ethical Aspects}

This investigation was conducted in accordance with Resolution No. 08430 of 1993 of the Colombian Ministry of Health and was considered to be "risk lesser than the minimum"(8). All study participants signed an informed consent form. In addition, the study was approved by the Ethics Committee, concept No.022-2018 issued by the Subcommittee of Bioethics through Act No.010 of May 21,2018 and complied with national and international standards for human research ${ }^{(9)}$.

\section{RESULTS}

A total of 362 records of the three ICUs were included, $64.64 \%$ (no: 234 ) belonging to the ICU in center one, followed by $22.38 \%$ (no: 81 ) to the ICU in center two and $12.98 \%$ (no: 47 ) to the ICU at center three. It was found that $62.01 \%$ of the patients (no: 222) were men, with a median age of 64.50 years (Q1:53.00-Q3:73.00). Moreover, $41.99 \%$ (no: 152 ) had a circulatory diagnosis, followed by $17.23 \%$ (no: 62 ) having a respiratory diagnosis and $12.43 \%$ (no: 45) having a central nervous system diagnosis. The median hospital stay was 3 days (Q1:2.00-Q3:7.00), see Table 1.

In Table 2, a general median of NAS is observed for the entire population of 68.1 points (Q1: 47.2-Q: 116.7) with

Table 1 - Sociodemographic and clinical characteristics of the population based on the health care institution - Bucaramanga, Colombia, 2019.

\begin{tabular}{|c|c|c|c|c|c|c|c|c|c|}
\hline \multirow[b]{2}{*}{ Characteristics } & \multicolumn{2}{|r|}{ All } & \multicolumn{2}{|r|}{ ICU 1} & \multicolumn{2}{|r|}{ ICU 2} & \multicolumn{2}{|r|}{ ICU 3} & \multirow[b]{2}{*}{$p$-value $¥$} \\
\hline & $\mathbf{n}$ & $\begin{array}{l}\text { \% or Median } \\
\text { (Q1-Q3) }\end{array}$ & $\mathbf{n}$ & $\begin{array}{l}\text { \% or Median } \\
\text { (Q1-Q3) }\end{array}$ & $\mathbf{n}$ & $\begin{array}{l}\text { \% or Median } \\
\text { (Q1-Q3) }\end{array}$ & $\mathbf{n}$ & $\begin{array}{l}\text { \% or Median } \\
\text { (Q1-Q3) }\end{array}$ & \\
\hline Age, years & 362 & $64.50(53.00-73.00)$ & 234 & $64.00(53.00-73.00)$ & 81 & $68.00(57.00-77.00)$ & 47 & $59.00(45.00-72.00)$ & 0.029 \\
\hline \multicolumn{10}{|l|}{ Gender } \\
\hline Female & 136 & 37.99 & 85 & 36.48 & 34 & 43.59 & 17 & 36.17 & 0.514 \\
\hline Male & 222 & 62.01 & 148 & 63.52 & 44 & 56.42 & 30 & 63.83 & \\
\hline \multicolumn{10}{|l|}{ Marital status } \\
\hline Single & 89 & 24.93 & 63 & 27.04 & 7 & 9.09 & 19 & 40.43 & \\
\hline Married & 149 & 41.74 & 92 & 39.48 & 39 & 50.65 & 18 & 38.30 & \\
\hline Cohabiting & 48 & 13.45 & 42 & 18.03 & 3 & 3.90 & 3 & 6.38 & $<0.001$ \\
\hline Divorced & 24 & 6.72 & 10 & 4.49 & 13 & 16.88 & 1 & 2.13 & \\
\hline Widowed & 47 & 13.17 & 26 & 11.16 & 15 & 19.48 & 6 & 12.77 & \\
\hline \multicolumn{10}{|c|}{ Socioeconomic level } \\
\hline Low & 191 & 53.06 & 146 & 62.39 & 34 & 42.50 & 11 & 23.91 & \\
\hline Medium & 165 & 45.83 & 88 & 37.61 & 46 & 57.50 & 31 & 67.39 & $<0.001$ \\
\hline High & 4 & 1.11 & 0 & 0.00 & 0 & 0.00 & 4 & 8.70 & \\
\hline
\end{tabular}


...continuation

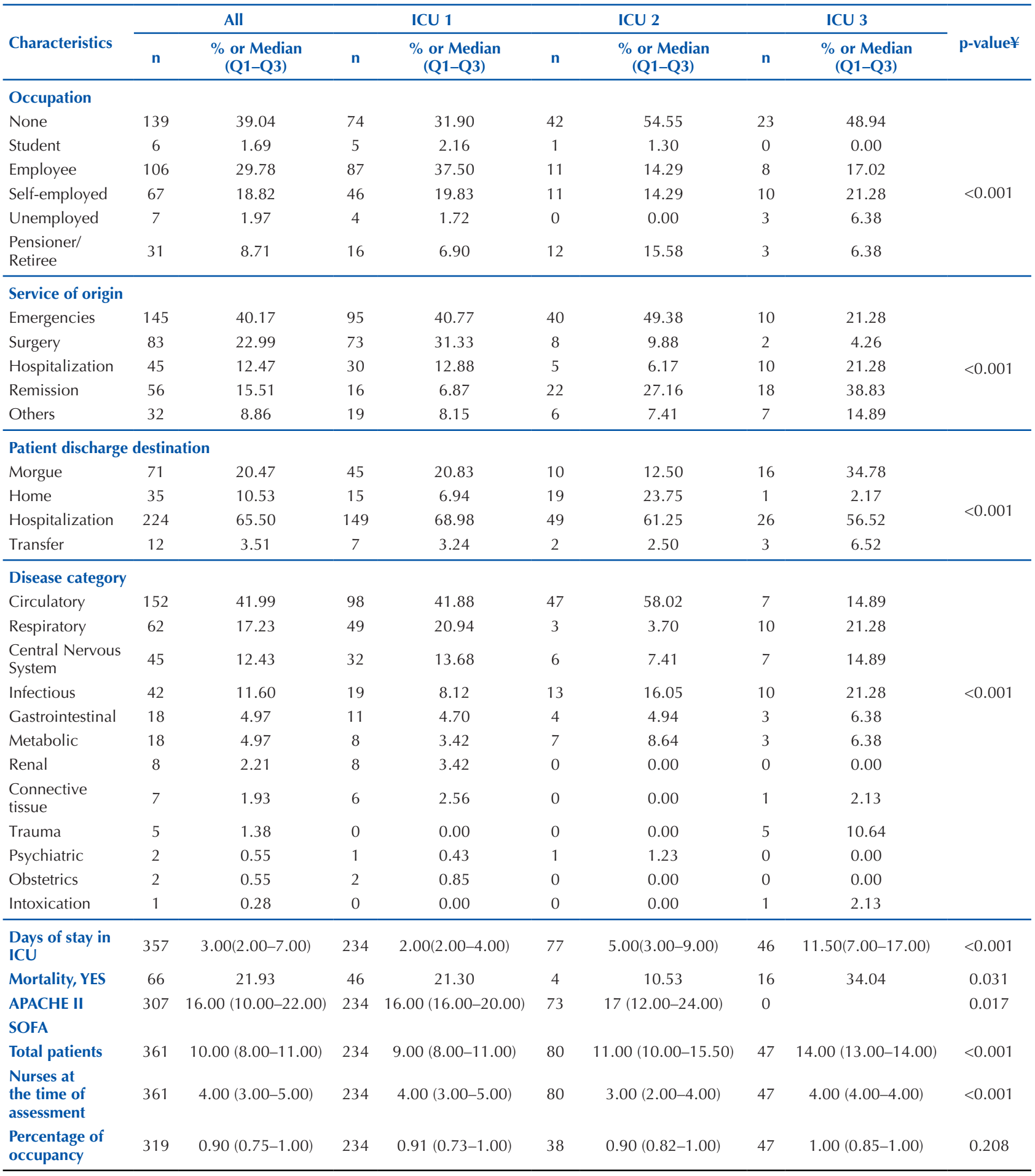

$¥$ Square Ji test for categorical variables and Kruskal-Wallis test for continuous variables.

differential trends between the centers, with a larger one at center two and a median of 102 [Q1:60.90-Q3:152.7], $\mathrm{p}-0.001$. Additionally, it is observed that $50 \%$ of nurses spend about $25 \%$ of their time on administrative tasks [Median: 27.40 [Q1:4.20-Q3:27.4.0]] with trend difference and statistical significance between the centers (p: 0.001), with the largest median expenditure at center number one Median: 27.4 [Q1:27.40-Q3:27.40], followed by other activity such as monitoring and control, mobilization and postural changes, renal support, and drug administration.

In Figure 1, a linear, direct, and weak correlation between NAS and APACHE II can be observed as the probability of death increases as the nursing workload increases.

In Figure 2, it can be observed that there is no relationship between the NAS score and the age of the patient, p. 0.987 . There is a linear relationship of up to about 40 years; 
Table 2 - General score trend and Nursing Activities Score activity for each study center - Bucaramanga, Colombia, 2019.

\begin{tabular}{|c|c|c|c|c|c|}
\hline \multirow{2}{*}{ Characteristic } & All & ICU 1 & ICU 2 & ICU 3 & \multirow{2}{*}{ p-valuet } \\
\hline & Median (Q1-Q3) & Median (Q1-Q3) & Median (Q1-Q3) & Median (Q1-Q3) & \\
\hline General NAS & $68.1(47.2-116.7)$ & $64.2(46-115.3)$ & $102.0(60.90-152.7)$ & 60.85 (51.8-68.25) & 0.001 \\
\hline Monitoring and control & $16.60(0-16.6)$ & $4.50(0.00-16.60)$ & $16.60(16.60-36.20)$ & $16.60(16.60-20.15)$ & 0.001 \\
\hline Mobilization and postural changes & $12.40(0.00-17.90)$ & $5.50(0.00-17.90)$ & $17.90(5.50-34.90)$ & $12.40(5.50-12.40)$ & 0.001 \\
\hline Renal support & $7.00(0.00-7.00)$ & $0.00(0.00-7.00)$ & $7.00(0.00-7.00)$ & $7.00(7.00-7.30)$ & 0.001 \\
\hline Medication administration & $5.6 .0(5.60-5.60)$ & $5.60(5.60-5.60)$ & $5.60(5.60-5.60)$ & $5.60(5.60-5.60)$ & 0.001 \\
\hline Laboratory procedure & $4.30(4.30-4.30)$ & $4.30(4.30-4.30)$ & $4.30(4.30-4.30)$ & $2.15(2.10-4.30)$ & 0.001 \\
\hline Hygiene interventions & $4.10(0.00-20.60)$ & $4.10(0.00-20.60)$ & $20.60(4.10-20.60)$ & $4.10(2.05-4.10)$ & 0.001 \\
\hline $\begin{array}{l}\text { Support and care of family members or } \\
\text { patients }\end{array}$ & $4.00(0.00-4.00)$ & $4.00(0.00-4.00)$ & $4.00(4.00-4.00)$ & $0.00(0.00-2.00)$ & 0.001 \\
\hline Specific interventions & $1.90(0.00-2.80)$ & $1.90(0.00-2.80)$ & $1.90(0.00-2.80)$ & $0.00(0.00-0.90)$ & 0.001 \\
\hline Ventilatory support & $1.40(0.00-7.60)$ & $1.40(0.00-5.80)$ & $4.40(0.00-7.60)$ & $2.30(1.40-5.40)$ & 0.002 \\
\hline Drainage care & $0.00(0.00-0.00)$ & $0.00(0.00-1.80)$ & $0.00(0.00-0.00)$ & $0.00(0.00-0.90)$ & 0.429 \\
\hline Neurological support & $0.00(0.00-0.00)$ & $0.00(0.00-000)$ & $0.00(0.00-0.00)$ & $0.00(0.00-0.00)$ & 0.265 \\
\hline Metabolic support & $0.00(0.00-1.30)$ & $0.00(0.0-1.3)$ & $0.00(0.0-1.30)$ & $1.30(1.30-2.80)$ & 0.001 \\
\hline
\end{tabular}

¥ Kruskal-Wallis test for the comparison of medians.

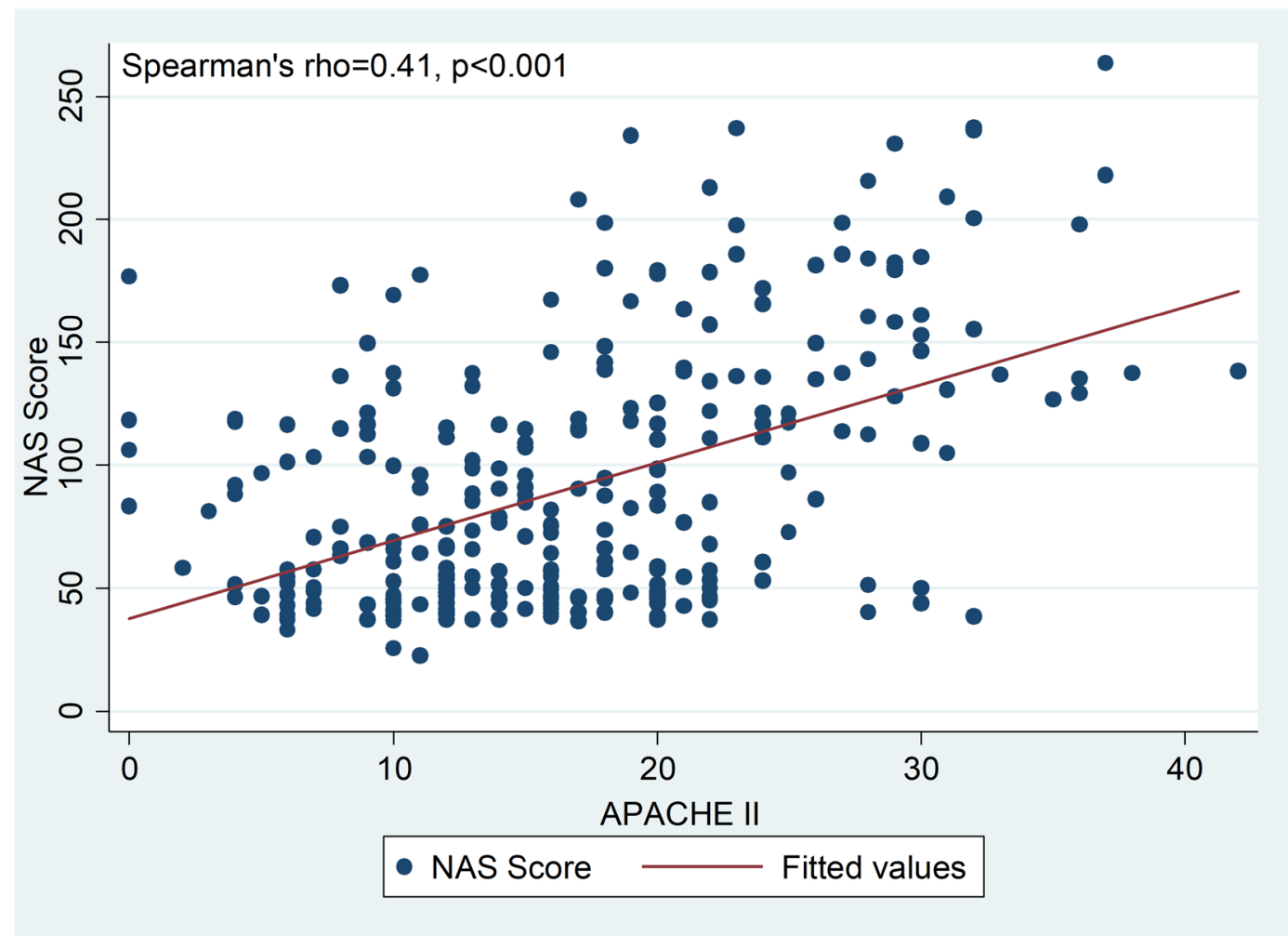

Figure 1 - Spearman correlation between nursing activity score and APACHE II.

after this point, the relationship seems to have a slight trend. Table 3 shows the raw and adjusted effects on the final model of each variable on the NAS score, highlighting that for each point increase in the APACHE II probability, the workload evidenced by the NAS increases on average by about three points from 3.13 (95\% CI: 2.28; 3.98). It is also evident that compared to patients who have less days of stay in ICU, those that have $>3$ days of stay have an average NAS score of 16.78 (95\% CI: 6.15; 27.41).
Moreover, there was a significant association for an increase in the NAS, with an average of 22.31 (95\% CI: 9.76; 34.86) points, for patients coming from surgery compared to those from emergencies. Similarly, an average difference of $\beta: 33.72$ (95\% CI: 9.90; 57.53) was found for patients with a diagnostic category related to traumatology and emergencies in relation to the infectious-metabolic category. Finally, a difference of 19.3 points was found in the NAS average per IPS as shown in Table 3. 


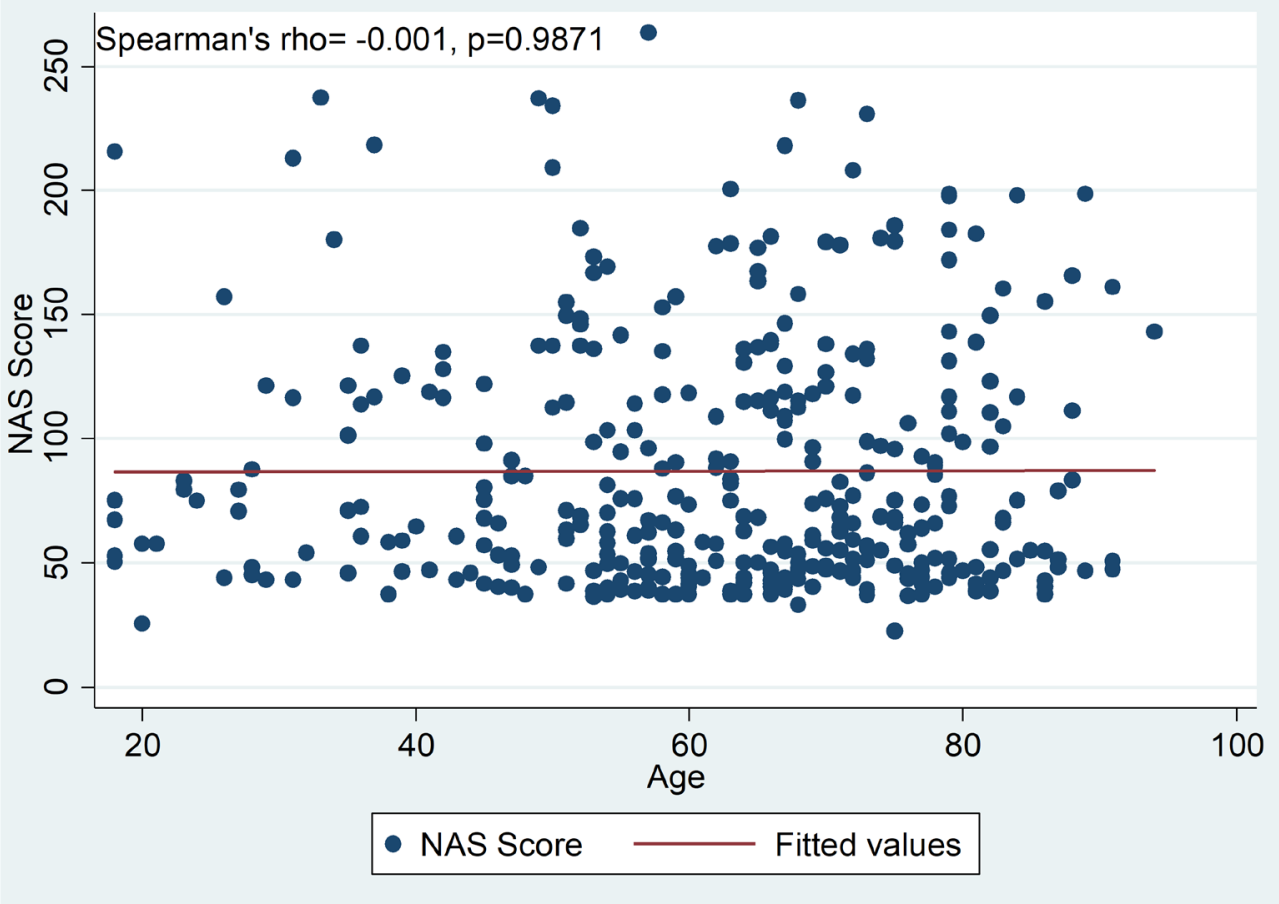

Figure 2 - Spearman correlation between the score of nursing activities and the age of the patient.

Table 3 - Percentage of NAS activity time stratified by each health institution - Bucaramanga, Colombia, 2019.

\begin{tabular}{|c|c|c|c|c|c|c|}
\hline \multirow{2}{*}{ Nursing Activities Score (NAS) } & \multicolumn{3}{|c|}{ Simple models: Raw effects } & \multicolumn{3}{|c|}{ Final model (R2: 42.48) (n:297) ¥¥ } \\
\hline & $\beta$ & Cl 95\% & $p ¥$ Value & $\beta$ & Cl 95\% & p Value* \\
\hline Age, years & 0.01 & $(-0.32 ; 0.34)$ & 0.995 & -0.31 & $(-0.64 ; 0.025)$ & 0.070 \\
\hline$\beta 0: 86.42$ & $\mathrm{R} 2=50.191$ & $(65.32 ; 107.52)$ & 0.000 & & & \\
\hline Gender & \multicolumn{6}{|c|}{ Reference: Female } \\
\hline Gender (male) & 0.65 & $(-10.38 ; 11.68)$ & 0.908 & 6.98 & $(-3.06 ; 17.04)$ & 0.172 \\
\hline$\beta 0: 86.44$ & $\mathrm{R} 2=50.30$ & $(77.44 ; 95.44)$ & 0.000 & & & \\
\hline Service of provenance & \multicolumn{6}{|c|}{ Reference: Emergency Department } \\
\hline Surgery & 13.59 & $(-0.08 ; 27.26)$ & 0.051 & 22.31 & $(9.76 ; 34.86)$ & 0.001 \\
\hline Hospitalization & 8.24 & $(-8.65 ; 25.15)$ & 0.338 & 11.65 & $(-8.37 ; 31.68)$ & 0.253 \\
\hline Remission & 3.27 & $(-11.71 ; 18.27)$ & 0.667 & -4.10 & $(-18.41 ; 10.19)$ & 0.572 \\
\hline Others & 4.66 & $(-15.85 ; 25.18)$ & 0.655 & 19.79 & $(-2.19 ; 41.78)$ & 0.007 \\
\hline$\beta 0: 81.70$ & $\mathrm{R} 2=49.93$ & $(73.94 ; 89.46)$ & 0.000 & & & \\
\hline Diagnostic category & \multicolumn{6}{|c|}{ Reference: Metabolic-Infectious } \\
\hline Metabolic sphere & -11.70 & $(-32.25 ; 8.86)$ & 0.264 & -3.10 & $(-23.83 ; 17.63)$ & 0.769 \\
\hline Cardiovascular & -19.41 & $(-34.22 ;-4.61)$ & 0.010 & -9.93 & $(-26: 53 ; 6.60)$ & 0.240 \\
\hline Gastrointestinal & 12.60 & $(-17.51 ; 42.72)$ & 0.411 & 15.02 & $(-12.12 ; 42.17)$ & 0.277 \\
\hline Traumatology and emergencies & 2.27 & $(-26.82 ; 31.38)$ & 0.878 & 33.72 & $(9.90 ; 57.53)$ & 0.006 \\
\hline$\beta 0: 99.71$ & $\mathrm{R} 2=49.37$ & $(86.22 ; 113.20)$ & 0.000 & & & \\
\hline APACHE II & 3.17 & $(2.44 ; 3.89)$ & 0.000 & 3.13 & $(2.28 ; 3.98)$ & 0.000 \\
\hline$\beta 0: 37.72$ & $\mathrm{R} 2=45.72$ & $(25.69 ; 49.76)$ & 0.000 & & & \\
\hline Days of stay in ICU & \multicolumn{6}{|c|}{ Reference: Days of stay in ICU } \\
\hline$\geq 3$ Days of stay in ICU & 17.99 & $(7.30 ; 28.70)$ & 0.001 & 16.78 & $(6.15 ; 27.41)$ & 0.002 \\
\hline$\beta 0: 75.99$ & $\mathrm{R} 2=49.43$ & $(67.39 ; 84.59)$ & 0.000 & & & \\
\hline Location IPS & \multicolumn{6}{|c|}{ Reference ICU 1} \\
\hline $\mathrm{UCl} 2$ & 24.04 & $(10.38 ; 37: 70)$ & 0.001 & 19.27 & $(3.88 ; 34.66)$ & 0.014 \\
\hline $\mathrm{UCl} 3$ & -23.72 & $(-30.99 ;-16.45)$ & 0.000 & - & - & - \\
\hline$\beta 0: 84.70$ & $\mathrm{R} 2=48.18$ & $(78: 26 ; 91.14)$ & 0.000 & & & \\
\hline
\end{tabular}

$¥$ Robust simple linear regression model; ¥ Robust simple linear regression model; ¥¥ Linear regression model including age, gender, provenance service, diagnostic category, days of stay, APACHE II score, and ICU center; * Adjusted robust multiple regression model p-value. 


\section{DISCUSSION}

This study was conducted with the aim of determining the nursing workload in three ICUs and the factors associated with it. The median NAS was 68.1 points (Q1:47.2Q3:116.7), with significant differences per center, $\mathrm{p}-0.001$. Administrative tasks took up most of the nursing time [Median: 27.40 (Q1:4.20-Q3:27.4.0)], with significant differences by center, $p-0.001$. APACHE II $(\beta=3.13$, CI $95 \%: 2.28 ; 3.98)$, days of stay in ICU $\geq 3(\beta=16.78$, CI: $95 \% 6.15 ; 27.41)$, surgical service of provenance $(\beta=22.31$, $95 \%$ CI: $9.76 ; 34.86)$, and diagnostic category of traumatology and emergencies ( $\beta=33.72$, CI 95\%: 9.90; 57.53) were associated with a high NAS score. Many of these factors have also been associated with the development of delirium in critical patients ${ }^{(10)}$, with a possible hypothesis being the increased nursing workload in these patients. In relation to the differences in the NAS scores presented at each center, a high score was found in ICU 2, mediated by high APACHE II index, high age, and high frequency in the circulatory category. These characteristics place patients in a situation of great severity and enhanced risk of dying, but still susceptible to recovery. This leads to a greater effort in constant care and more consumption of both material and human resources ${ }^{(11)}$.

Globally, several countries have estimated the nursing workload in ICUs through the NAS, i.e., Spain, with 65.9 $9^{(12)}$, Croatia with $77^{(13)}$, Holland with $43^{(14)}$, and Iran with $113.6^{(15)}$. In a previous work carried out in our country by this research group, an initial result of 60.51 in an ICU of high complexity was obtained ${ }^{(16)}$. This variability in the NAS values should be analyzed in light of the nurse ratio established in each country, which varies in different continents. For instance, in Europe there is a 1:1 relationship, while in Latin America, some countries still do not have an ideal nurse-patient ratio, as is the case with our country ${ }^{(17)}$. The results of this study indicate that more nurses would be required to provide optimal care. In our current context, this ratio may be 1:3,1:4, or even higher.

Regarding these findings, it is necessary to highlight the need to carry out such studies in our country where the patient-nurse ratio is not standardized according to the care needs of our context. In this respect, recent studies in the Netherlands and Belgium found that the NAS score per nurse was associated with hospital mortality, while the patient-nurse ratio was not ${ }^{(18-19)}$. These results highlight workload overestimation, this being a reality in many ICUs in developing countries where the mortality rates have traditionally been attributed to patient factors.

In Latin America, Brazil has been a pioneer in studies establishing nurse workload in ICUs. These values are slightly higher than the average of other countries, with average NAS values of $76.9^{(20)}$. However, some studies show that this workload is consistent with the nurse ratio, such as the study of Dos Santos et al.., illustrating that the activities most performed by the nurses were monitoring and control and hygiene procedures, which agree with the findings of the present study ${ }^{(21)}$. These results further highlight the need to assess the workload impact in different contexts and to individualize the patient-nurse ratio according to the needs and uniqueness of each ICU.

In relation to population characteristics, an important fact is that most patients included in our study were older adults. This is relevant as it has been described that this variable can increase the NAS score as found in a study in Brazil, where each year of age increased the NAS score by 0.081 points ( $\mathrm{p}: 0.015)^{(22)}$. This observation further suggests the need to include an analysis of population characteristics when performing patient assignment or calculating the nurse-patient ratio for an ICU.

Among the identified correlations were aspects of interest such as diagnostic category (traumatology and emergencies), $>3$ days of stay, mortality, and APACHE II index, finding statistical significance in relation to the increase of NAS. The results related to the type of service are similar to those described in a study conducted at different hospitals in Iran, where the correlation with a high NAS score was evident for nurses of patients from the emergency department and surgery. The findings assert the importance of assessing the workload in different units ${ }^{(23)}$. With regard to patient severity evaluated using mortality scales and its relationship with increased workload, the results are consistent with those reported in other studies where patient criticality increases the NAS score ${ }^{(6,24)}$.

This hints the need for a dynamic adjustment of the nurse ratio in ICU, which is in line with the criticality of patients, the complexity of the functions of each health institution, the care needs of users and families, and also the absenteeism and rotation indicators of the nursing staff( ${ }^{(25)}$. This study found that the different centers vary according to the clinical characteristics of the patients being treated. Additionally, each institution has its own strategic objectives and goals when facing internal quality processes in healthcare. This topic is highly relevant in the current coronavirus disease - 2019 pandemic, where a first study in Italy has revealed an increase of up to $33 \%$ in NAS in ICU patients with this diagnosis ${ }^{(26)}$.

Finally, considering that a high workload has been described as a risk factor for attention-associated infections that impact the quality of care, such as the onset of phlebitis, pneumonia, and pressure ulcers ${ }^{(21,27-29)}$, it is necessary to highlight the importance of establishing a nurse-patient that is in line with the workload. This is important as there are many modifying factors, such as direct and indirect care, type of patients, and schedules and shifts ${ }^{(30)}$.

Considering the above points, this article aims to create a process in which there is greater visibility of our discipline in our country through new contributions that lead to improving the quality of nursing care. A national-level multicenter study to describe the workload across the country should be carried out in the future.

As this research is a multicenter study involving three reference centers in Santander and is analytical in nature, the information can be extrapolated to nursing workload trends throughout the department. 
There was a loss of subjects in various variables of interest in the study, which introduced differences in the sample size and led us to lose samples. Therefore, precision in some estimators of the multivariate model could have been compromised.

\section{CONCLUSION}

Overall, half of the nursing professionals spend approximately $68 \%$ of their shift time on a single critical patient, with this having a differential trend in various ICUs and reaching more than $100 \%$ of the time in ICU 2 , which reflects the high workload. Administrative work is the most time-consuming task for the staff, followed by other activities such as monitoring and control, mobilization and postural changes, renal support, and drug administration. Additionally, hospital stays of longer than 3 days, high APACHE II score, coming from the surgery department, and having a diagnosis of trauma and emergency were associated with a high workload.

\section{RESUMEN}

Objetivo: Determinar la carga la laboral de enfermería en Unidades de Cuidado Intensivo y los factores asociados al puntaje del Nursing Activities Score. Método: Estudio analítico, de corte transversal realizado en tres Unidades de Cuidados Intensivos de Bucaramanga, Colombia entre febrero del 2018 y febrero del 2020. La carga de enfermería fue estimada con el Nursing Activities Score. Se realizó un análisis descriptivo y bivariado estratificado por UCI a través de un modelo de regresión lineal múltiple robusta se estimaron los factores asociados a la carga de enfermería $(\mathrm{p}<0,05)$. Resultados: 362 registros fueron incluidos. La mediana del NAS fue 68.1 puntos (Q1:47.2-Q3:116.7) El APACHE II ( $\beta=3.13$, IC 95\%: 2.28; 3.98), días de estancia en UCI 33 ( $\beta=16.78$, IC 95\%: 6.15; 27.41), servicio de procedencia cirugía $(\beta=22.31$, IC $95 \%$ : 9.76; 34.86), categoría diagnostica traumatología y urgencias $(\beta=33.72$, IC $95 \%$ : $9.90 ; 57.53)$ se asociaron a mayor puntaje del NAS. Conclusión: El personal de enfermería emplea aproximadamente el $70 \%$ de un tiempo en un solo paciente y las labores administrativas ocupan la mayor parte de su tiempo. La estancia hospitalaria mayor de tres días, el mayor puntaje del APACHE II, proceder del servicio de cirugía, el tener un diagnóstico de traumatología y urgencias se asociaron a una alta carga laboral.

\section{DESCRIPTORES}

Carga de Trabajo; Enfermería de Cuidados Críticos; Unidades de Cuidados Intensivos.

\section{RESUMO}

Objetivo: Determinar a carga de trabalho de enfermagem em Unidade de Terapia Intensiva e os fatores associados ao escore NAS. Métodos: Estudo analítico transversal realizado em três UTIs de Bucaramanga, Colômbia, entre fevereiro de 2018 e fevereiro de 2020. A sobrecarga de enfermagem foi estimada com o Nursing Activities Score (NAS). Foi realizada análise descritiva e bivariada estratificada por UTI por meio de modelo de regressão linear múltipla robusto e estimados os fatores associados à sobrecarga de enfermagem ( $<<0,05)$. Resultados: Foram incluídos 362 registros. O NAS mediano foi de 68,1 pontos (Q1: 47,2-Q3: 116,7) APACHE II ( $\beta=3,13$, IC $95 \%: 2,28 ; 3,98)$, dias de permanência na UTI $\geq 3$ ( $\beta=16,78$, IC $95 \%: 6,15 ; 27,41)$, serviço de origem da cirurgia ( $\beta=22,31$, IC $95 \%$ : $9,76 ; 34,86)$, categoria de diagnóstico de trauma e emergências ( $\beta=33,72$, IC 95\%: 9,90; 57,53) estiveram associados a maior pontuação NAS. Conclusões: a equipe de enfermagem da UTI despende aproximadamente $70 \%$ do tempo com um único paciente e as tarefas administrativas ocupam a maior parte do tempo. A permanência hospitalar superior a três dias, maior pontuação do APACHE II, proveniente do serviço de cirurgia, com diagnóstico de trauma e urgências estiveram associados à elevada carga de trabalho.

\section{DESCRITORES}

Carga de Trabalho; Enfermagem de Cuidados Críticos; Unidades de Terapia Intensiva.

\section{REFERENCES}

1. Arango G, Peña B, Vega Y. Relación de la asignación de personal de enfermería con indicadores de resultado de la calidad de la atención en unidades de cuidados intensivos de adulto. Aquichan. 2015;15(1):90-104. https://doi.org/10.5294/aqui.2015.15.1.9

2. Chang LY, Yu HH, Chao YC. The relationship between nursing workload, quality of care, and nursing payment in Intensive Care Units. J Nurs Res. 2019;27(1):1-9. https://doi.org/10.1097/jnr.0000000000000265

3. Oliveira AC, Garcia PC, Nogueira LS. Nursing workload and occurrence of adverse events in intensive care: a systematic review. Rev EsC Enferm USP. 2016;50(4):683-94. https://doi.org/10.1590/S0080-623420160000500020

4. Greaves J, Goodall D, Berry A, Shrestha S, Richardson A, Pearson PG. Nursing workloads and activity in critical care: a review of the evidence. Intensive Crit Care Nurs. 2018;48:10-20. https://doi.org/101016/j.iccn.2018.06.002

5. Padilha KG, Stafseth S, Solms D, Hoogendoom M, Monge FJC, Gomaa OH. Nursing Activities Score: an updated guideline for its application in the Intensive Care Unit. Rev Esc Enferm USP. 2015;49:131-7. https://doi.org/10.1590/S0080-623420150000700019

6. Nobre RAS, Nascimento Rocha HM, Santos FJ, Santos AD, Mendonça RG, Menezes AF. Application of Nursing Activities Score (NAS) in different types of ICUs: an integrating review. Enferm Global. 2019;18(4):515-28. https://doi.org/106018/eglobal.18.4.362201

7. StataCorp. Stata statistical software for data science. College Station, Texas; 2003.

8. Colombia. Ministerio de Salud. Resolución 8430 de 1993 Por la cual se establecen las normas científicas, técnicas y administrativas para la investigación en salud [Internet]. Colombia; 1993 [cited 2020 Mar. 25]. Available from: https://www.minsalud.gov.co/sites/rid/Lists/ BibliotecaDigital/RIDE/DE/DIJ/RESOLUCION-8430-DE-1993.PDF

9. Asociación Médica Mundial. Declaración de Helsinki de la AMM: principios éticos para las investigaciones médicas en seres humanos [Internet]. Córdoba; 2008 [cited 2020 Mar. 25]. Available from: http://www.wma.net/es/30publications/10policies/b3/17c_es.pdf

10. Torres-Contreras CC, Páez-Esteban AN, Hinestrosa-Díaz Del Castillo A, Rincón-Romero MK, Amaris-Vega A, Martínez-Patiño JP. Factors associated with delirium in critical patients in a health institution in Bucaramanga, Colombia. Enferm Intensiva. 2019;30(1):13-20. https:// doi.org/10.1016/j.enfi.2018.03.002 
11. Saltos Rivas M, Pérez Cardoso CN, Suárez Mella R, Linares Giler SM. Análisis de la carga laboral del personal de enfermería, según gravedad del paciente. Rev Cubana Enferm [Internet]. 2018 [cited 2020 Mar. 18];34(2). Available from: http://www.revenfermeria.sld.cu/ index.php/enf/article/view/2170

12. Valls-Matarín J, Salamero-Amorós M, Roldán-Gil C. Análisis de la carga de trabajo y uso de los recursos enfermeros en una unidad de cuidados intensivos. Enferm Intensiva. 2015;26(2):72-81. https://doi.org/10.1016/j.enfi.2015.02.002

13. Kraljic S, Zuvic M, Desa K, Blagaic A, Sotosek V, Antoncic D, et al. Evaluation of nurses' workload in intensive care unit of a tertiary care university hospital in relation to the patients' severity of illness: A prospective study. Int J Nurs Stud. 2017;76:100-5. https://doi. org/10.1016/j.ijnurstu.2017.09.004

14. Armstrong E, de Waard MC, de Grooth HJ, Heymans MW, Reis Miranda D, Girbes AR, et al. Using Nursing Activities Score to assess nursing workload on a Medium Care Unit. Anesth Analg. 2015;121(5):1274-80. https://doi.org/10.1213/ANE.0000000000000968

15. Alizadeh M, Heidari Gorji M A, Khalilian A R, Esmaeili R. Assessment of nursing workload and related factors in Intensive Care Units using the Nursing Activities Score. J Mazandaran Univ Med Sci [Internet]. 2015 [cited 2020 June 28];24(122):147-57. Available from: http://jmums.mazums.ac.ir/article-1-5295-en.html

16. Cáceres D, Torres C, Cristancho L, López L. Carga laboral de los profesionales de enfermería en unidad de cuidados intensivos: estudio descriptivo: «CARETIME». Acta Colomb Cuid Intensivo. 2020;20(2):92-7. https://doi.org/10.1016/j.acci.2019.12.002

17. Arango G, Peña B, Vega Y. Relación de la asignación de personal de enfermería con indicadores de resultado de la calidad de la atención en unidades de cuidados intensivos de adulto. Aquichan. 2015;15(1):90-104. https://doi.org/10.5294/aqui.2015.15.1.9

18. Margadant C, Wortel S, Hoogendoorn M, Bosman R, Spijkstra JJ, Brinkman S, et al. The Nursing Activities Score per nurse ratio is associated with in-hospital mortality, whereas the patients per nurse ratio is not. Crit Care Med. 2020;48(1):3-9 https://doi.org/10.1097/ CCM.0000000000004005

19. Bruyneel a, Tack J, Droguet M, Maes J, Wittebole X, Reis Miranda D, Di Pierdomenico L. Measuring the nursing workload in intensive care with the Nursing Activities Score (NAS): prospective study in 16 hospitals in Belgium. J Crit Care. 2019;54:205-11. https://doi. org/10.1016/j.jcrc.2019.08.032

20. Pereira BDSL, Pereira SRM, Farias AMMD, Bridi AC, Paula VGD, Souza KAD. Aplicação do Nursing Activies Score (NAS) em uma Unidade de Terapia Intensiva (UTI). Rev Pesq. 2020;12:78-86. http://dx.doi.org/10.9789/21 20205-5361.rpcfo.v12.7052

21. Trettene AS, Luiz AG, Razera APR, Maximiano TO, Cintra FMRN, Monteiro LM. Nursing workload in specialized Semi-intensive Therapy Unit: work force size criteria. Rev Esc Enferm USP. 2015;49(6):960-66. https://doi.org/10.1590/s0080-623420150000600012

22. Ferretti-Rebustini REL, Nogueira LS, Silva RCG, Poveda VB, Machado SP, Oliveira EM, et al. Aging as a predictor of nursing workload in intensive care unit: results from a Brazilian sample. Rev Esc Enferm USP. 2017;51:e03216. http://dx.doi.org/10.1590/s1980$220 \times 2016237503216$

23. Moghadam KN, Chehrzad MM, Masouleh SR, Mardani A, Maleki M, Akhlaghi E, et al. Nursing workload in intensive care units and the influence of patient and nurse characteristics. Nurs Crit Care. 2020 Sept 20. https://doi.org/10.1111/nicc.12548

24. Nassiff A, de Araújo TR, Gonçalves Menegueti M, Bellissimo-Rodrigues F, Basile-Filho A, Laus AM. Carga de trabalho de enfermagem e a mortalidade dos pacientes em Unidade de Terapia Intensiva. Texto Contexto Enferm. 2018;27(4):e0390017. https://doi.org/10.1590/010407072018000390017

25. Díaz CR, Gutiérrez H, Amancio AM. Ausentismo y desempeño laboral en profesionales de enfermería de áreas críticas. Rev Cuid. 2018;9(1):1973-87. http://dx.doi.org/10.15649/cuidarte.v9i1.426

26. Lucchini A, Giani M, Elli S, Villa S, Rona R, Foti G. Nursing Activities Score is increased in COVID-19 patients. Intensive Crit Care Nurs. 2020;59:102876. https://doi.org/10.1016/j.iccn.2020.102876

27. Gomes FA, Brito Röder DVD, Cunha TM, de Oliveira R. The nursing workload assessed through the Nursing Activities Score as a predictor for the occurrence of ventilator-associated pneumonia in an adult Intensive Care Unit. J Nurs Educ Pract. 2019;9(9):104-14. https://doi. org/10.5430/jnep.v9n9p104

28. Nogueira TDA, Menegueti MG, Perdoná GDSC, Auxiliadora-Martins M, Fugulin FMT, Laus AM. Effect of nursing care hours on the outcomes of Intensive Care assistance. PLoS One. 2017;12(11):e0188241. http://dx.doi.org/10.1371/journal.pone.0188241

29. Barros FRB. Adesão ao bundle de prevenção de pneumonia associada à ventilação mecânica. Rev Cuidarte. 2019;10(2):e746. http:// dx.doi.org/10.15649/cuidarte.v10i2.746

30. Souza P, Cucolo DF, Perroca MG. Nursing workload: influence of indirect care interventions. Rev Esc Enferm USP. 2019;53:e03440. http:// dx.doi.org/10.1590/S1980-220X2018006503440 